\title{
SCHEMATICAL PRESENTATION OF VIBRATION OF PATHOLOGICAL VOCAL CORDS
}

YUKI KAKITA, Ph.D., MINORU HIRANO, M.D., HIROSHI KAWASAKI, M.D, and HIDEAKI MATSUSHITA, M.D.

Department of Otolaryngology School of Medicine, Kurume University, Kurume

(Director: M. Hirano, M.D.)

Vibratory mode of the vocal cords in seven different pathological conditions was investigated by frame-by-frame analysis of ultra high speed motion pictures. The pathological laryngeal conditions investigated were recurrent laryngeal nerve palsy, sulcus vocalis, polyp, polypoid vocal cord, amyloid tumor, epithelial hyperplasia, and carcinoma. On the basis of the data obtained movements of the vocal cord in a frontal section within one vibratory cycle in each pathological conditions were schematically presented where the vocal cord was regarded as a double layered vibrator. Furthermore, some comparisons of vibratory mode among the different conditions were studied with a special attention to the maximum amplitude and the maximum velocity of lateral excursion of the vocal cord, which are related to the mass, elasticity, viscosity, and interferences by the counterpart.

A79-1553-61020

\section{病的 声 带 振 動 の 模 式 的 表 示}

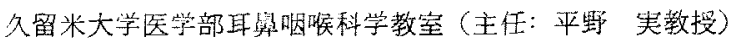
坦田有紀・承野実・川崎洋・松下英明

\section{I. 粕言}

我々は先に超高速度撮影で記録したフィルム省分析し て, 振動中の正常声带の前額断面儿蛙けるらるまい学模 式的飞表示した

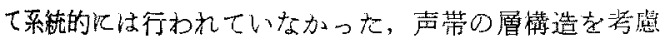
するととあに，上方からの観祭では見觉ない声带下面の 動き飞ついては定量的な推定を行った。

前報告ては正常声帯飞ついての続果を示したが，本報 告で病的な場合について，7種の例安示を。

\section{II. 模式図作製の手がかりと手順}

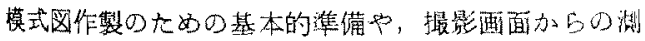
定に関しての詳細は前の報告に示したが，所㒻を述べる

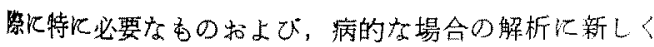
加党たものにつて次に示す。

超高速度映画の画面の計測汇関しては，まず，フィル

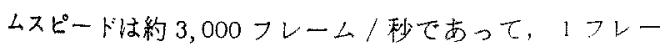
么の示す時間は $0.33 \mathrm{~ms}$ ，血るいは3フレームで $1 \mathrm{~ms}$ の現象を示している，次㓅，長さの基準としては，四仅
声带間の長さを6 mmで一定佔であると仮定した。非対 称な場合や，片側が視野に入っていない場合は，片㑡の

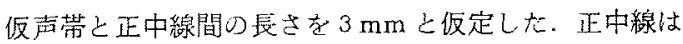
振動が非刘称で方っても，前連合(視野に入っていない) 之两接裂軟骨声带实起の中点を結忍線を視祭によって予 浿して決定した，たたし，反回神経麻瘏のさうに，披裂 軟骨の位置も非対称な場合は，健側声带縁がは添淔線に なったと专の位置（代償性過肉転は起っていない）とし た。声率の前額断面の基本形は, 発声中の声帯のラリン

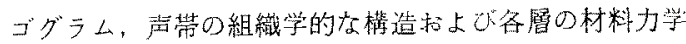
的な性質など齐考感して，等価的二層棈造とし，表面を カバー、媣部ばディと定義しだ、。

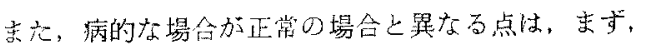
变位の測定に際して一方が蜮側でもう一方が患側( いは両方が患側)であるため, 左右の侕带の動きは一般

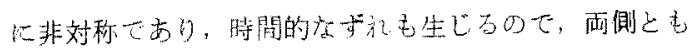
测定する必要がある，さらに前額断闻图の作製侮して

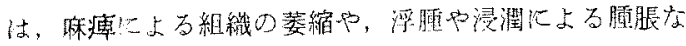




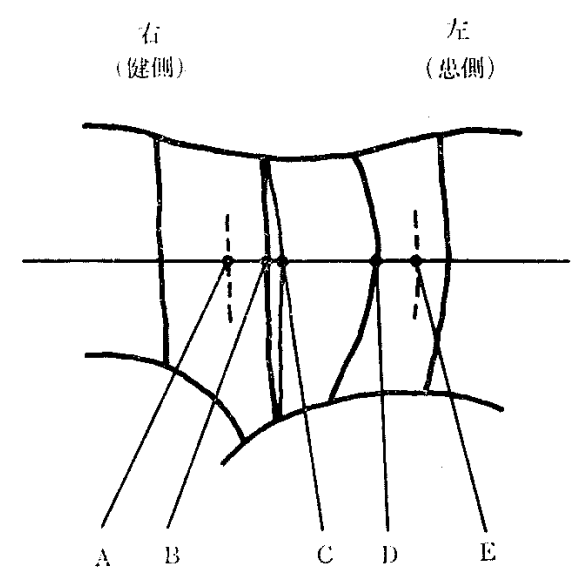

図 1 a 反回神経麻疸の例の声帯の略図と測定点

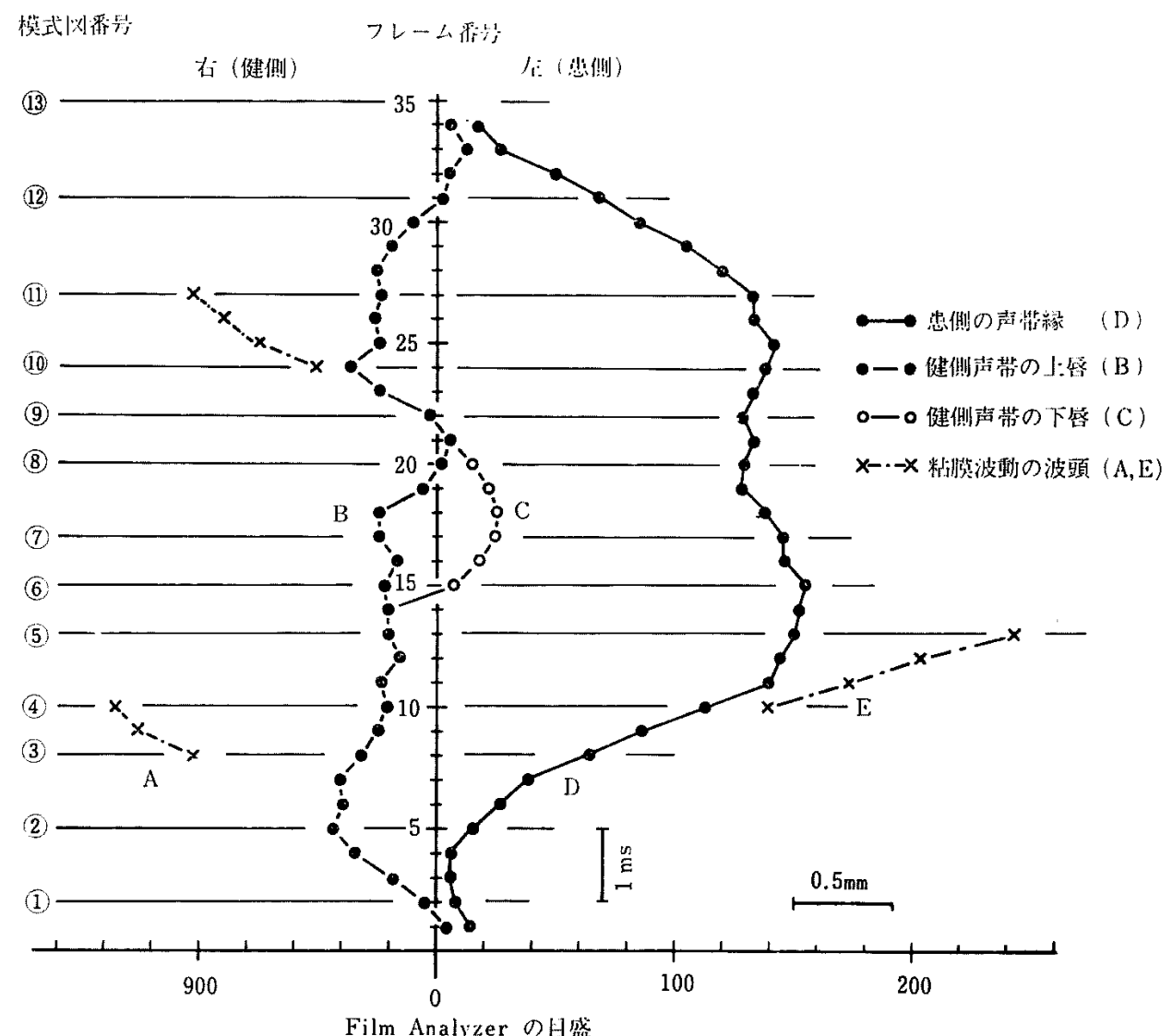

図 $1 \mathrm{~b}$ 図 $1 \mathrm{a}$ K示した点の水平方向恋位の時間变化 


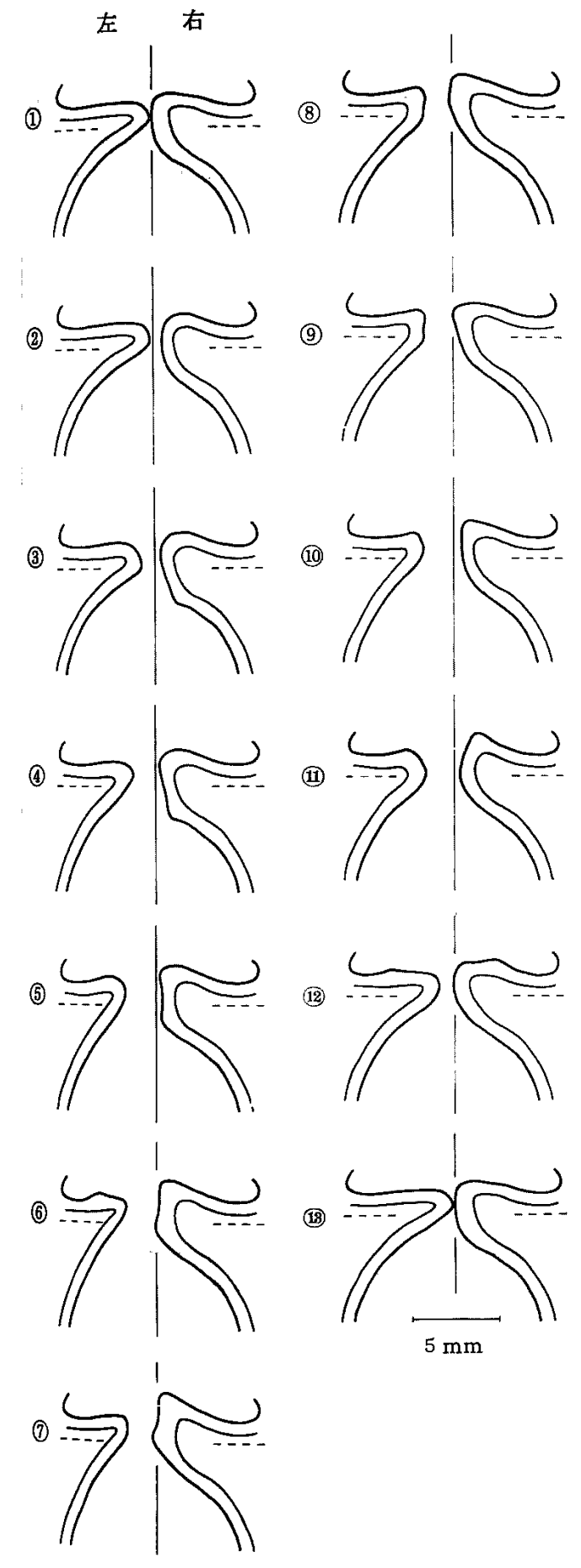

図 2 前額断面での声帯振動の模式図 (反回神経麻疩，患側左）
どを考虑して,カバーやボディの断面秷を適宜堌減した。 それから，喉頭鏡に上る上方からの観測で見ることの できない声帯下面の粘膜波動の様子については，上面に 観測できるすのを湘定して得た位置と速度を参考に, 速 度は一定と仮定して, 計算により位置を推定した。

\section{田 . 病的声帯の振動状態の解析之模式図 \\ 1. 反回神経麻瘏の例}

図 1 a K示す声带上面の略図中 $\mathrm{A} \sim \mathrm{E}$ までの記号をつ けた 5 点について測定した水平変位の時間変化を 図 $1 \mathrm{~b}$ に示す．AとEはそれぞれ健側（右）と患側（左）の粘 膜波動の波頭，B とＣ はそれぞれ健側声帯の上唇と下 唇, Dは患側の声帯縁を示す. 両声帯の動きは著しく非 対称て，また両声帯が完全飞相い接することはない. 2 つの最大閉小期の間は，患側の 1 周期飞相当し，これが 基本周期であるが, 健側ではその期間に 2 度の開閉運動 を示している. 患側の 1 周期 (基本周期) は, 33フレー ム分となるので周期 $11 \mathrm{~ms}$ ，したがって基本周波数は約 $90 \mathrm{~Hz}$ となる.一方，この音声の音響分析の結果では約 $170 \mathrm{~Hz}$ の值が得られていることと，聴覚的にす $170 \sim$ $180 \mathrm{~Hz}$ 辺りの高さに聴こえることから，この例の場合， 音声波の段階での基本周波数は健側の振動の方が強く反 映していると考えられる。

模式図の対象として選んだのは図 1 b の (1) (19)で示 したフレームであり，これをすとに作製した模式図を図 2 に示す.患側のボディの断面積は筋の萎縮と収縮障害 を考慮して，健側の約60\%と仮定した。これは形態学的 な結果より推定した，以下主な所見を記す。

i) (1) は最小閉小期で, 两声带の間隍は約 $0.2 \mathrm{~mm} て$ ある。健側の上唇 (B) は約 $0.5 \mathrm{~m} / \mathrm{s}$ の速度で開大を始 めたところであり(2)まで開大が続く．患側（D）は一時 健側飞近ずき，そのあと健側より約 $7 \mathrm{~ms}$ 幄れて開大し 始める。

ii）(2) ては健側は第 1 周期目の最大開大期にあって, 正中からの水平変位は $0.5 \mathrm{~mm}$ である。このあと(4)まで $0.1 \mathrm{~m} / \mathrm{s}$ の速度で閉小していく. 患側 (D) は(2)から(3) までは $0.4 \mathrm{~m} / \mathrm{s}$ ，(3)から (4)の次のフレームまでは 0.8 $\mathrm{m} / \mathrm{s}$ で開大し，後者は最大の開大速度を示している。ま た(3では, 健側の声帯縁加ら $1 \mathrm{~mm}$ 外側飞粘膜波動の波 頭 (A) が現われ， $0.5 \mathrm{~m} / \mathrm{s}$ の速度て外側飞向って移動 しつつ隇衰し，(4)で消隇する。この粘膜波動の波頭の変 位は，(1)から(2)の健側の変位のちょうご延長上飞あるこ とから，(2)で健側が折り返した際に外側へ向って生じた 衙慗によって新たに発生した波と考えられる，一方これ 
とは別K, のちに上面に現れる波頭の位置と速度加ら逆 算して，両声帯の下方に，吹きあげによる粘膜波動が生 じはじめていると推測される，健側では肁平上皮下端付 近，患側では下方遊離縁付近飞波頭がある。

iii) (4)から(7)までは，健側の上唇はわずかに動いては
いるが，ほぼ正中から0.25 mmの位置で停滞している. 患側では，(5から6にかけて，最大開大期を示す，水平 変位柱約 $1.8 \mathrm{~mm}$ である.さらK(4)で声帯縁 (D) 加ら $0.5 \mathrm{~mm}$ 外倒にわずかに粘膜波動の波頭 (E) が現れる. これも(3)からの健側の波頭と同椂に, 折り返しの衝轱に

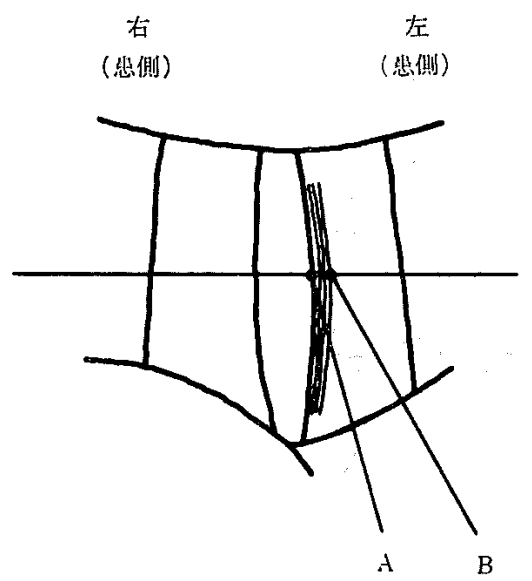

図 $3 \mathrm{a}$ 声帯溝症の例の声帯の略図と湘定点

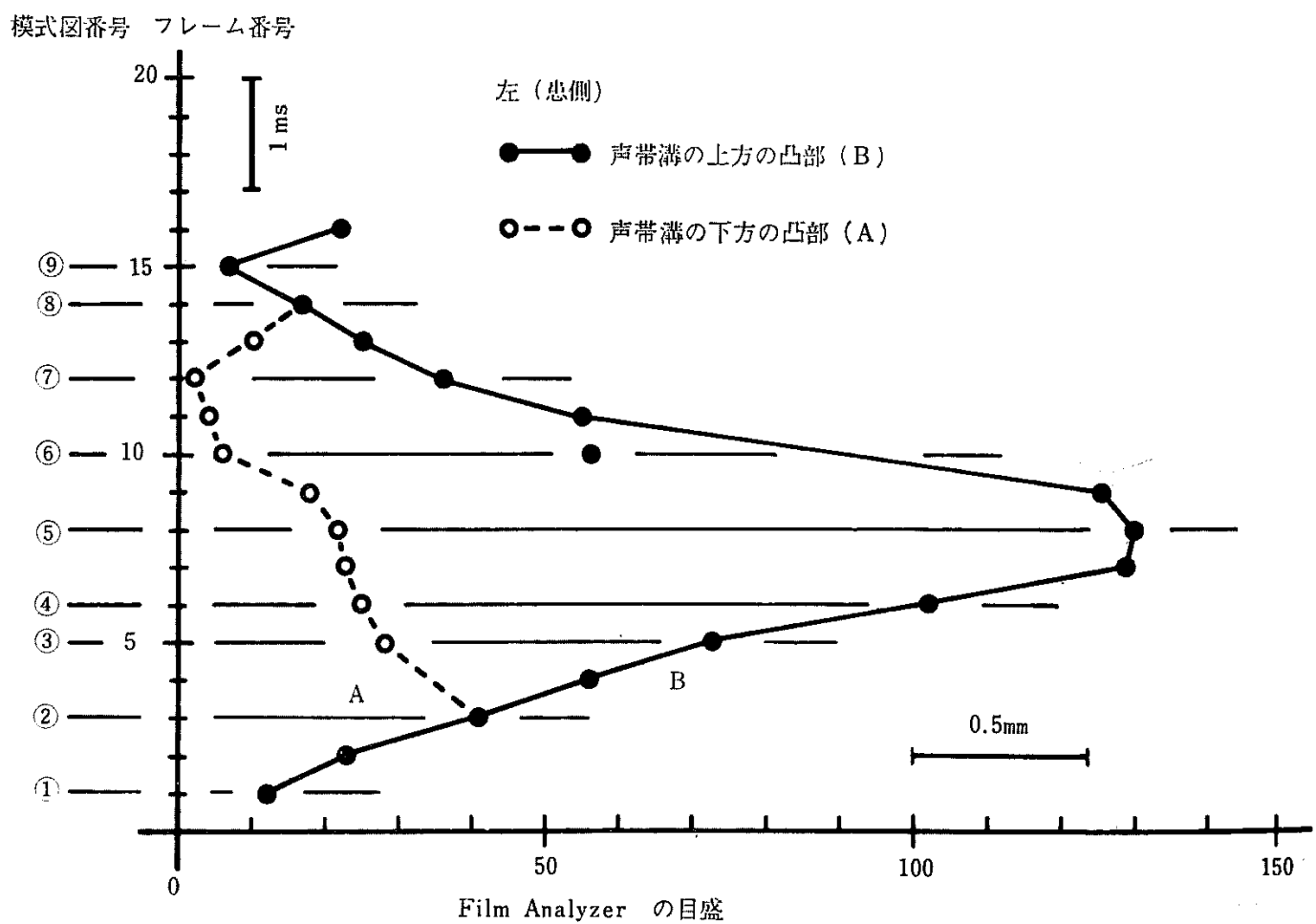

図 $3 \mathrm{~b}$ 図3aK示した点の水平方向变位の時間変化 


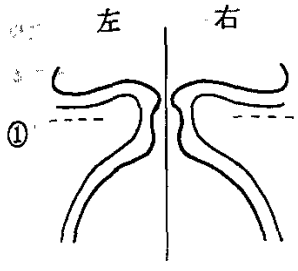

(6)

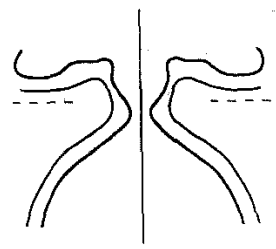

(2)

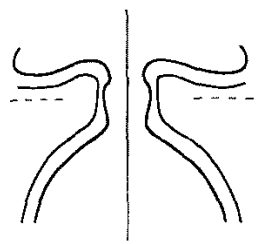

(3)

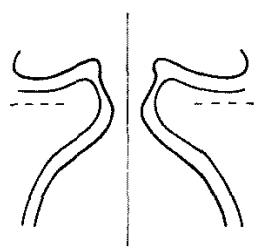

(4)

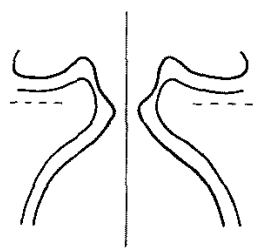

(5)

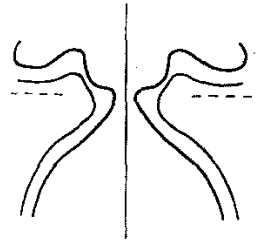

图 4 前額断面での声帯振動の模式図 (声帯满症, 患側両側)

よって生じたと考光られ，(2)から(4)まてと同じ $0.8 \mathrm{~m} / \mathrm{s}$

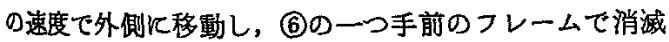
する.患側ではボディとカバーのスティフネスの差が少 ないので顕著な波は起らない，一方，吹きあけによって 生じた粘膜波動は上方に移動するが，健㑡ではまだ視野 K入らず，患側では，声帯の先端に到羍する。

iv) (6)て，健側では吹きあけとよる波が視野炕入っ $\tau$ ，下唇 (C) として認められ， $0.7 \mathrm{~m} / \mathrm{s}$ の速度で正中 を越えて患側に复入する，この侵入は(7)で最大となり，

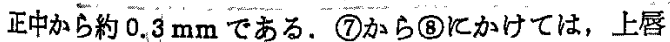
は $0.3 \mathrm{~m} / \mathrm{s}$ ，下唇は $0.1 \mathrm{~m} / \mathrm{s}$ の速度で互いK接近し，(8) の炏のフレームでは下唇は見总なくなる，(7)で健側の第
1 周期目がおわる。患側では，(6から(8にかけて約 0.2 $\mathrm{m} / \mathrm{s}$ でゃや閉小する.

v）(8)から(10亿かけて健㑡は，(1)から(2)とほほ同じよ うな様子で，速度あ等しく $0.4 \mathrm{~m} / \mathrm{s}$ で開大し，(10)第 2 番目の最大開大期示す．その後四们向ってわずが閉 小する.忠側では(8)か四にかけて正中より約 $1.5 \mathrm{~mm}$ の位置でほとんと停滞しているが，(10でもう一度わずか に外側に開大してもどる.また，(8)で両側の下側に 2 番 目の吹きあげKよる波が生じると推測される. (10)で健側 停满の先端加 50.2 mm 外側飞粘膜波動の波頭 (A) が 現われ， $0.7 \mathrm{~m} / \mathrm{s}$ で外側飞向って移動し，(10て消隇する.

vi）健側では(11)の次のフレームから(12)2フレームあ とに加けて閉小期を示し，閉小速度は $0.3 \mathrm{~m} / \mathrm{s}$ である。 患側では团から四の2フレームあとにかけてやはり閉小 期を示し，閉小速度は $0.8 \mathrm{~m} / \mathrm{s}$ である.このあと(18)で(1) の状態にもどる。

\section{2. “声帯满症の例}

超高速度撮影の画面では，角度の関係で右側の清は視 野に入っていないので，左側の動きを膜様部ほほ中央で （図 $3 a$ ）水平変位を测定して（図 $3 b$ )，模式図を描い た（図4).ストロボスコープKよる観察では左右の動き はほほ対称的であったので，右側は左側と刘称に図示し た. 声帯瑇症では病变の部位は扁平上皮領域のカバーの 部分に限られる。な特, 瑇による凹みより上の凸部を上 突部 (図 $3 \mathrm{a}$ の点A)，下の凸部老下突部（図 $3 \mathrm{a}$ の点 $\mathrm{B}$ ) と呼ぶことにする。

i ）(1)は上突部の最小閉小期であるが, 完全閉鎖は起 こらず，正中線加ら約 $0.25 \mathrm{~mm}$ 变位している，上突部 は(1)から(5)ず，約 $1.3 \mathrm{~m} / \mathrm{s}$ の速度で開大し，(5)で最大 開大期となる.このときの水平变位は約 $2.8 \mathrm{~mm}$ である. 一方下突部は (2)から諗められ $0.6 \mathrm{~m} / \mathrm{s}$ の速度で閉小す る. (2)は声带全体としての最大閏大期で, その水平夜位 は $0.8 \mathrm{~mm}$ である.

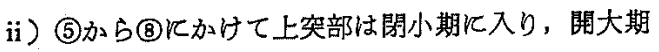
とほほ等しい速度て閭小する，下突部は6から(7)にかけ て最小閉小期となりこのときも完全な閉鎖は起こらず, $0.05 \mathrm{~mm}$ 程度正中から変位している. (7)から(8)Kかけ て下突部は開大る始め，(8で上突部にかくれて見えなく なる.

この振動の1周期は15フレームであるから $5 \mathrm{~ms}$ ，した がって基本周波数は $200 \mathrm{~Hz}$ である.

3. 声帯ポリープの例

水平変位の测定の対象としたのは，図 5a の A D 点 
で，患側ではポリープの外縁 (A) と内縁 (B), 趾側で は声帯縁（C）と粘膜波動の波頭 (D)である.ポリープ が趾側に特呿いか心゙さってCが視野に入らない場合は， ポリープの前後の視野に入る部分からその位置を推測し
た. 各点の水平変位の時間変化と，それにもとずいた模 式図を，それそれ図5bと図6亿示す。声帯ポリープあ 病変は遊離縁部のカバーのみK限られ，ポリープの部分 だけ体皘が增加している.この例は浮腫が主病変なので

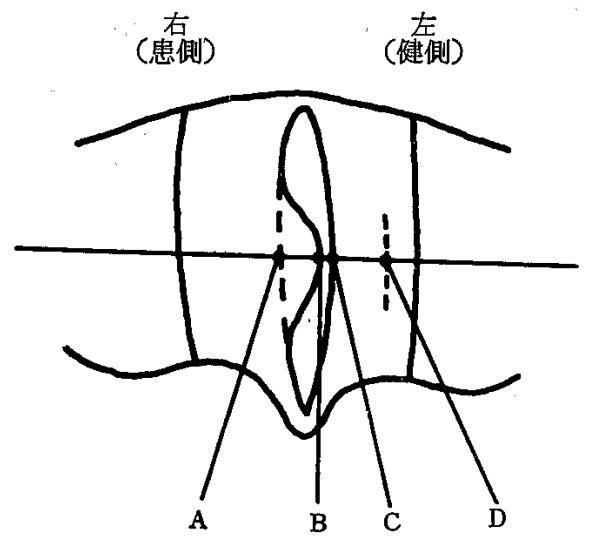

模式図番号

図 5 a 声帯ポリープの例の声帯の略図と測定点

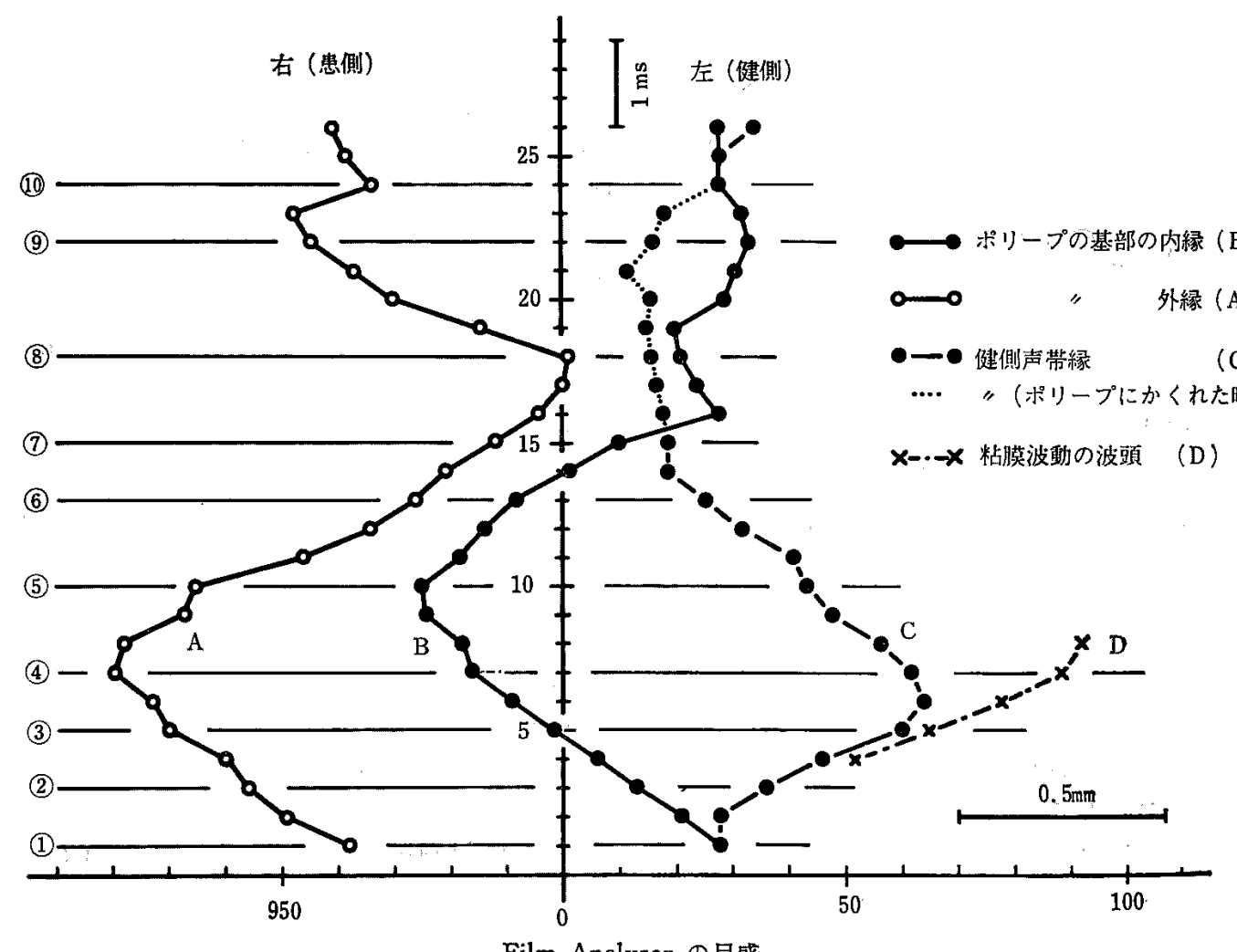

Film Analyzer の目盛

図 $5 \mathrm{~b}$ 図5ak示した点の水平方向変位の時間変化 


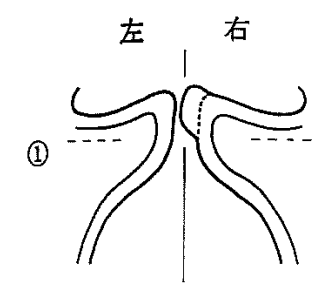

(6)

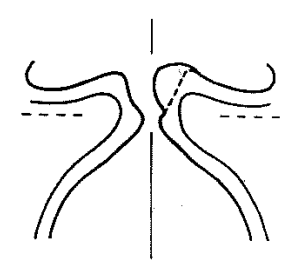

(2)

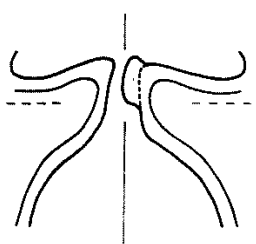

(3)

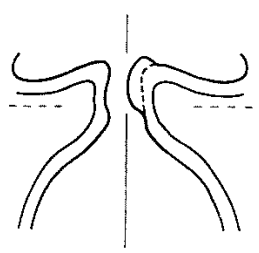

(4)

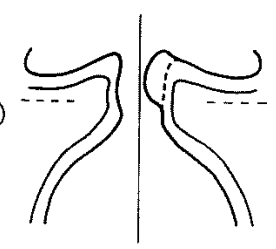

(5)

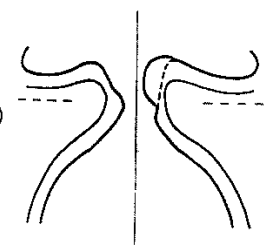

(7)

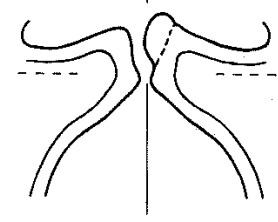

(8)

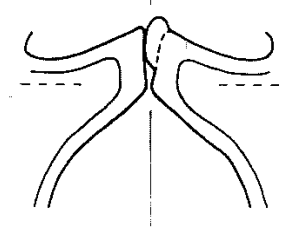

(9)

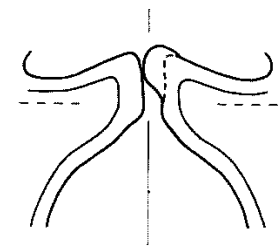

(10)

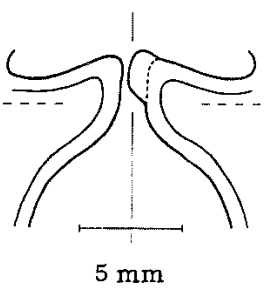

図 6 前額断面での声帯振動の模式図 （声帯ポリープ，患側右）

材質的には，外力による变形がかなり容易に起こる。

図 5b加らわ加るように，A点とB点の間隔が，閉小 期婂はとなり開大期には大となっている.すなわらポ リープは閉小期に健側声帯と接触して押しつぶされ，開 大期にはそれがあとにあどる。観察に際してはさらにそ の動きに伴って，押しつぶされるときは上方へ，もとに あどるとき方方へ，と首振り運動を行なう。模式図で はこれらの動きの特徴す加味してある。

i) (1)は上からの視野では，ポリープの外縁 (B) と 健側の声帯縁が接しているように見えるが，実際は 0.2 mmの間隙をのこしてはなれている。(1)から(3からにか

けて健側声带は呼気の吹きあげによって $0.5 \mathrm{~m} / \mathrm{s}$ の速度 で開いていき，(3加ら(4)に加けて最大開大期となり，そ の水平变位は $0.8 \mathrm{~mm}$ である. (3)の1フレーム前から健 側に現われはじあた粘膜波動の波頭は $0.5 \mathrm{~m} / \mathrm{s}$ の速度て 外側飞移勤し, (4)の 2 フレーム後で消堿する.一方, 患 側では，おしつぶされていたポリープがもとにもどりな がらわずか下方化首をらりつつ $0.3 \mathrm{~m} / \mathrm{s}$ の速度て開大 する.

ii) (4)から (7)まで徤側は開大時の $1 / 2$ の速度 $(0,25$ $\mathrm{m} / \mathrm{s}$ ) で閉小していく，患側では声帯（A）が閉じはじ めるが，ポリープはすぐにはそれに追随できず，しだい に颃しつぶされ，上方湴をふりながら声帯より少し遅 れて閉小していく.

iii）(7〜9)まで健側声帯は，ポリープとの接触によっ て停滞する．患側は(8)で最小閉小期となりポリープは最 あおしつぶされる.しかし患側の固有の声帯と健側声帯 とは相い接しない。(8から(9)にかけては，ポリープが物 しつぶされた反動で患側声帯を执しもどす。゚リープの 先端はほぼ停滞している. (10)で再び両側の開大が開始さ れ(1)の状態にもどる.

この振動の 1 周期は23フレームであるから, 約 $7.6 \mathrm{~ms}$, したがって基本周波数は， $130 \mathrm{~Hz}$ である.

4. 㭿リープ様声帯の例

上面からの声帯の略図を図7a亿示す。この例では病変 は両側にある. 水平変位測定の対象としたのは図 $7 \mathrm{a}$ に 示す $A \sim E$ D 5 点で, 夙側のポリープ样腫脹の内縁 (C, D)，外縁 (B，E)，と粘膜波動の波頭 (A) てある. 各点の水平变位の時間変化と, それにもとずいた模式図 を，それぞれ図7b と図8沅示す．本症も病変はカバー のみに限られ，病変の部分だけ体積が增加している. 浮 腫性病変が主体なので材質的には变形が容易に格こる。

図 $7 \mathrm{~b}$ からあかるように 1 周期のほほ $1 / 2$ の期間飞わ たって両側のポリープ様腫脤部は接触しており，接触し たまま同じ方向に変位する現象がみられる。さらにそれ に伴ってかなりの変形を示す．病変部の外縁の動きは著 明でく、したがって声帯の变位の变化は大きくない。 この例次蛒いても耐声帯の固有の部分は相い接しない 粘膜波動はポリープ㥞腄脹の外縁よりも外側化は正常の 場合上同様に観湘された。

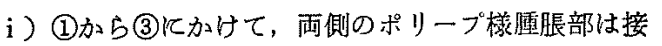
触したまま右方へ $0.1 \mathrm{~m} / \mathrm{s}$ で变位していく.しかしその 外縁恬これと逆仿ず加左方へ向って变位していく，し たがって，右側のポリープ様腫脹部は圧縮变形をうけ， 


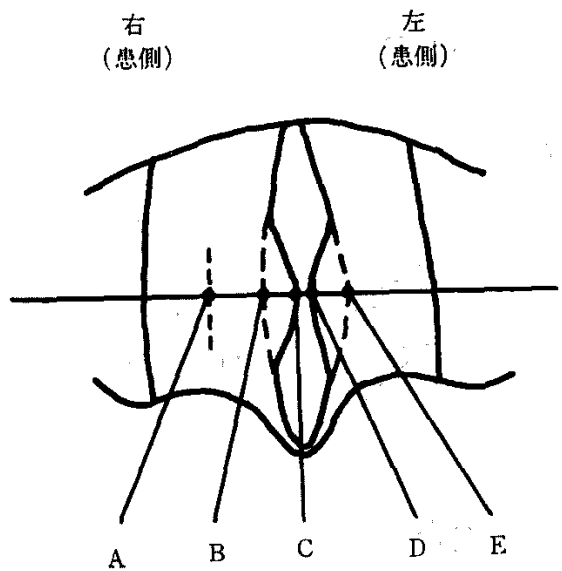

図 $7 \mathrm{a}$ ポリープ様声帯の例の声帯の略图と湘定点

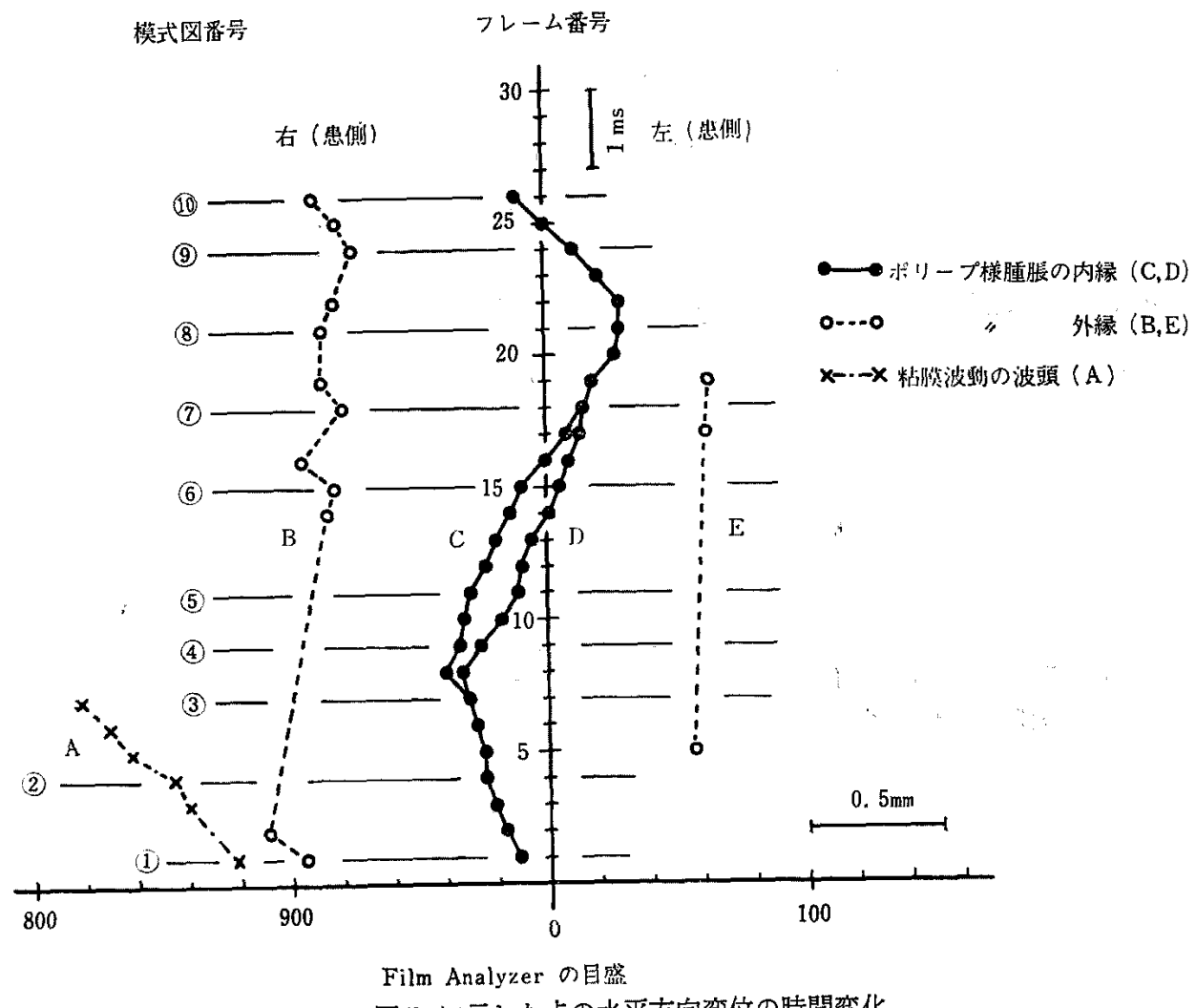

図 $7 \mathbf{b}$ 因 $7 \mathrm{a}$ に示した点の水平方向変位の時閻変化 


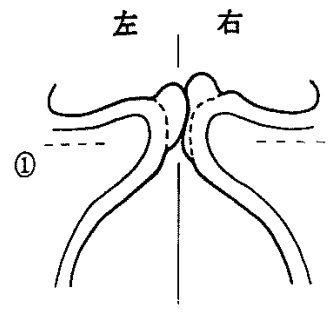

(6)
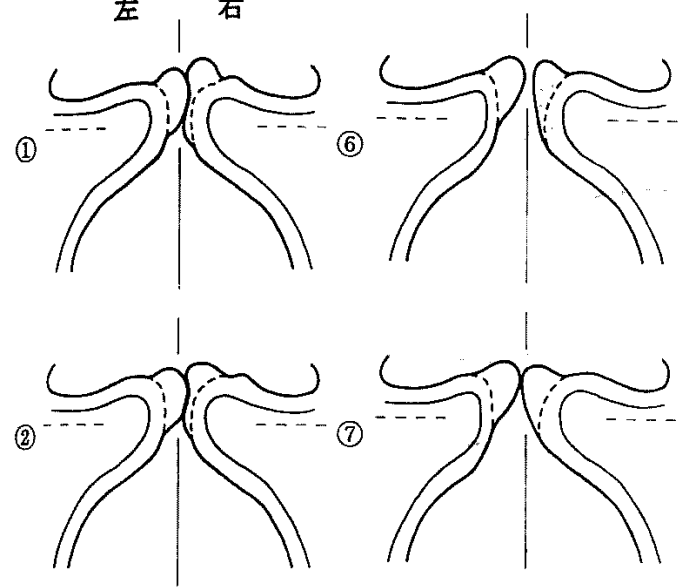

(3)

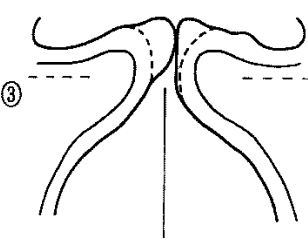

(8)
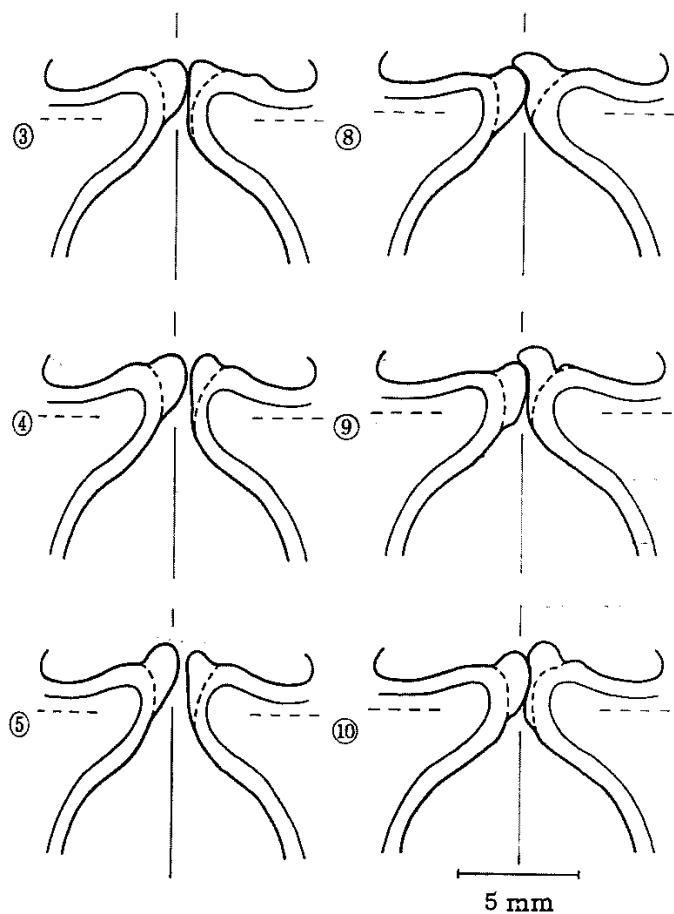

図 8 前額断面での声帯振動の模式図 (ポリープ様声帯，患側両側）

左僋のそれは体張する。一方, (1)で右側声帯のポリープ 㥞隀唇部の外縁辺りから粘膜波動が生じ, $0.3 \mathrm{~m} / \mathrm{s}$ の速 度で外㑡飞向って移動し(3で消隇する。

ii）(3から(5)までは，両側のポリープ様腫脹部がはな れて声門は開大をはじめ，同時飞両側とも並行に 0.15 $\mathrm{m} / \mathrm{s}$ の速度で左方に移動する。代縮されていた腫脹部は らくらみ屺め，はずみで下方晌って首をふる。（5か
ら66までは声閒の最大開大期である，(6)から(7)までは再 び閉小しはじめる.これに伴って右側のポリープ滕腫脹 は左側のそれの上から括括いから゙さるように交形する。

iii）(7)から(9)までは再び両側ポリープ様病変部が接触 したままである。(7)から(8)にかけては，右側が左側にさ らに和格いから゙さるが，(8)で折りかえして右側はしだい に王縮されはじめる. (9)加ら(10がほほ最小閉小期の様相 を示して括り，(10で再び(1)の状態ともどる.

この振動の 1 周期は 25 フレームであるから $8.3 \mathrm{~ms}$, したがって基本周波数は $120 \mathrm{~Hz}$ である.

\section{5. アミロイド腫瘍の例}

上面からの声帯の略図を四9a亿示す＼cjkstart左声帯に大きな 属湯があり，振動周期全体飞わたって常飞右健側声帯の 上面飞接触している. 水平変位の測定対象としたのは, 四のA D までの 4 点で, 盾瘍の先端頭部内縁 (A) と 外縁 (B, 頭部は著明飞白くなっている)，堙煌の基部の 境界 (C)，执よび健側の声帯縁 (D) である. 点 D注常 に腫汮の下にあるため明視できないので腫瘍の前後の観 测可能な部分からその位置を推定した. 各点の水平変位 の時間变化と，それ飞るとずいた振動の模式図を，それ ぞれ図9b と図10亿示す病变は，遊離縁部のカバーに 限られ有荃性で，その部分の体積が堌加している，材質 的火はポリープよりも硬い。

缠瘍は常時健側声帯飞接触していて, 声帯振動飞伴っ て健側声帯の上面を滑りながら首ふり運動をする。

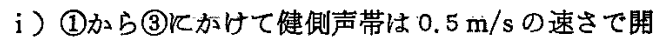

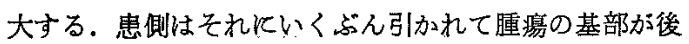
方に移動する．同時に腫場は下方飞首をらりはじめ，(3) で最も横にねた形となる. (3)から(4)は健側声帯の最大開 大期で水平変位は $1 \mathrm{~mm}$ である.

ii) (4)から(7)Kかけて健側声帯は $0.3 \mathrm{~m} / \mathrm{s}$ で閉小して いく．患側の睡瘍はそれに招されて上方に首をあち上げ ながら左方に移動する。

iii）(7から98で健側はさらに閉小を続ける。患側の 缠湯は健側炕接触して招かされ，基部の方が頭部より著 明飞右方にあどりつつある。須部の首らりもまた逆行少 しずつ下方に向う. (10で(1)と同じ状態にも゙る.この状 懸が最小閉小期である.

この振動の 1 周期は 19 フレームであるから $6.4 \mathrm{~ms}, し$ たがって基本周波数は $160 \mathrm{~Hz}$ である。

6. 上皮肥厚性疾患の例

上面から見た声帯の略图を图:11江示す。この例は両 㑡性の上皮肥厚性疾㭧で，肥厚した上皮は各声帯上面を 


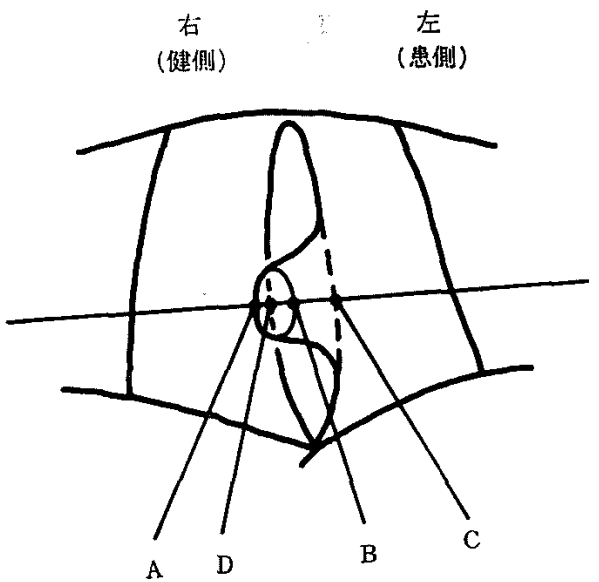

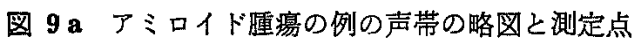

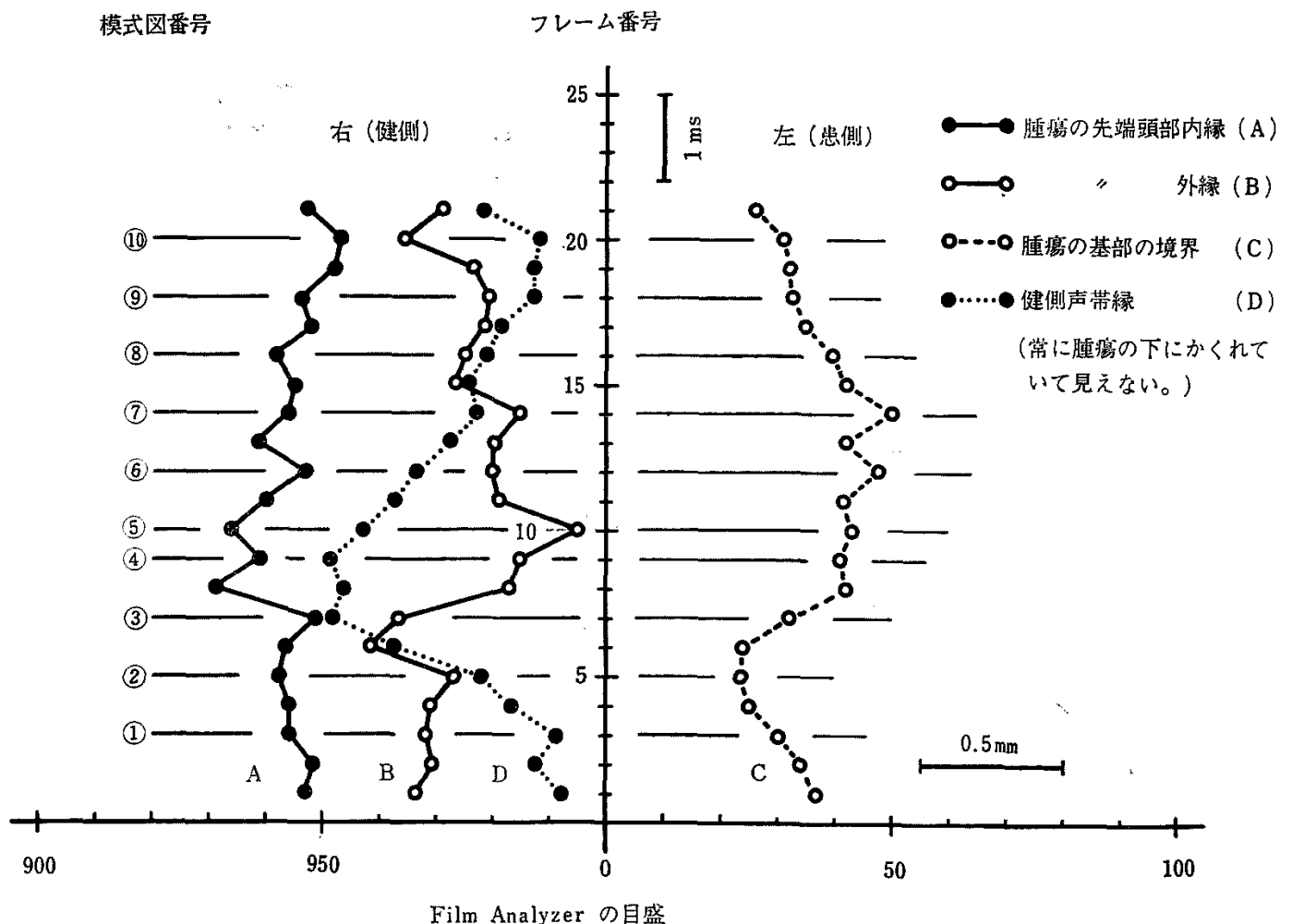

図 $9 \mathrm{~b}$ 図9a亿示した点の水平方向变位の時間变化 


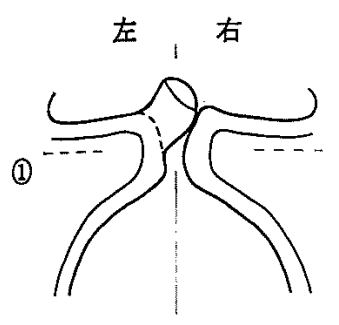

(6)
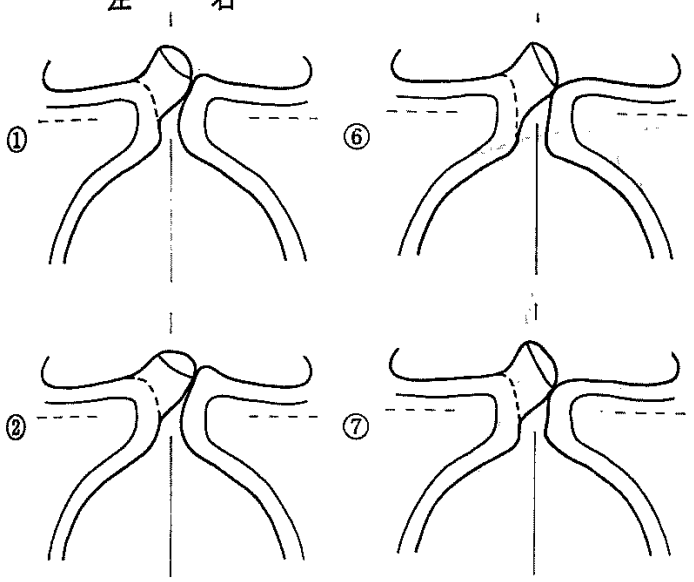

(7)

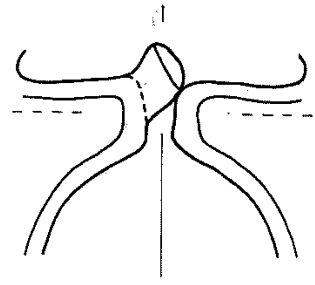

(3)

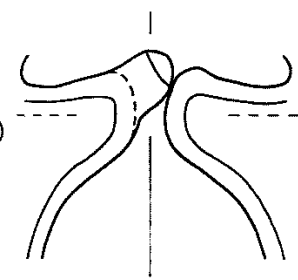

(8)

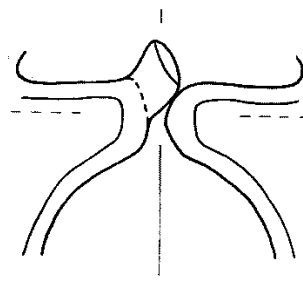

(4)

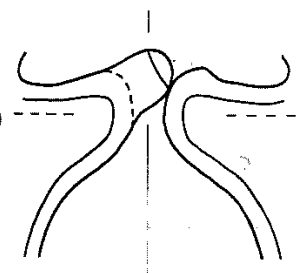

(5)

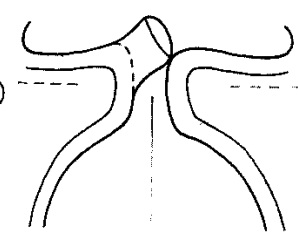

(10)
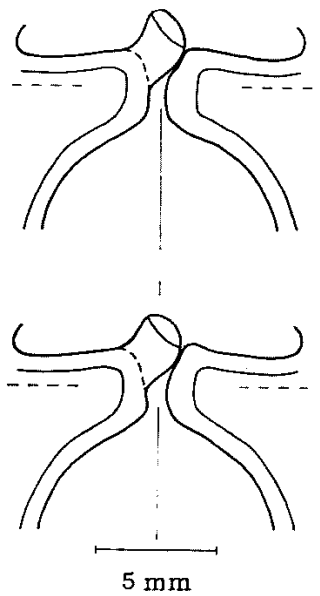

図 10 前額断面での声帯振動の模式図 （アミロイド腫瘍，患側左）

䄪 $1 \mathrm{~mm}$ の幅で括括っている. 水平変位の測定対象とし たのは, 図の $A \sim F$ までの6点て, 両側の声帯縁 (C, D) 括よび上皮肥厚部の内側の境界 $(\mathrm{B}, \mathrm{E})$ と外側の境 界 $(\mathrm{A}, \mathrm{F})$ である. 各点の水平変位の時間变化と，それ kもとずいた振動の模式図をそれそれ図11bと図12K示 す.病変部は遊離縁より喉頭室側の上皮で，カバーに限 られる.材質的にはかなり硬く，変形はあまり起こらな
W

振動中の声带の動きは極めて㧕制されている．図 $11 \mathrm{~b}$ より最大開大期と最小閉小期の声門間隙の差が $0.4 \mathrm{~mm}$ 程度しかなく, 上皮肥厚部の外側の境界はほとんど変位 を示さない。振動の特徾は，水面浮んだボートのよう に上皮肥厚部が横ゆれを示し，吹きあげよる粘膜波動 は下方加ら上っきても肥厚部分に衝突して消隇する.

i ) (1)から (4)まで右㑡声带縁 (C) は $0.05 \mathrm{~m} / \mathrm{s}$ でゆる 中加開大し，左側 (D) はむしろそれにほほ並行して 右側へ移動する。(2)で最大閔大期となり，(4)まてこの間 隙を保持する，一方肥厚部は声带縁よりあ少し迤れて， (4)で最大開大期となる。ま，(1)で，吹きあげによる粘 膜波動が 扁平上皮領域の下縁付近飞発生すると考光ら れ，(5)でほほ上皮肥厚部の内側飞到達して消隇すると推 湘される。

ii）声帯縁は(4)から閉小しはじめ，6て最小閉小期之 なる．完全閉鎖は起こらず，声門間隙の幅は $0.1 \mathrm{~mm}$ ある. 肥厚部すやはり (4)から閉小を示すが, 少し遅れて (7)の1フレーム後で最小閉小期となる。また(6) 2 番目 の粘膜波動が扁平上皮領域の下縁付近に発生して上昇し (8)から(9)にかけて肥厚部に到達して消滅すると推測され ๖.

iii) 声帯縁は(7)から，上皮肥厚部は(8)から再び開大期 に入り，(10まで閒大を続ける. 右側の声帯縁が(8)か観 測されなくなるが，肥厚部とほぼ同時加，少し早あに開 大しているのではないかと推測される. (10で再び(1)の状 態にもとる。

この振動の 1 周期は 17 フレームであるから $5.7 \mathrm{~ms}$, したがって基本周波数は $175 \mathrm{~Hz}$ である.

7. 喉頭癌の例

声帯の上面からの略図を図 13aに示す，右側声帯にか なり幅広く㽷ができて甜り，動きはほとんどない，水平 変位の測定対象は図で A C の 3 点で, 癌の内上縁 $(A)$, 癌の内下縁 (B) 叔よび健側の監帯縁 (C) である. 各点 の水平変位の時間変化と, それにもとずいた振動の模式 図を，それぞれ図13bと図14亿示す。

癌の部分は質量が大きいと同時に材質的にかなり硬 く，さらに浸溜がボディにまで及んでいるため，変形は ほとんと起らず，振動中湆とんど動かない，約 $0.1 \mathrm{~mm}$ 以下の変位と，その慣性によるわずかな首らり運動を示 すにすきない，健㑡声帯むとの影響を受けて最大水平变 位が約 $0.3 \mathrm{~mm}$ 程度しかない，粘膜波動も，㭧側はもち ろんのこと健側にも生じない。 


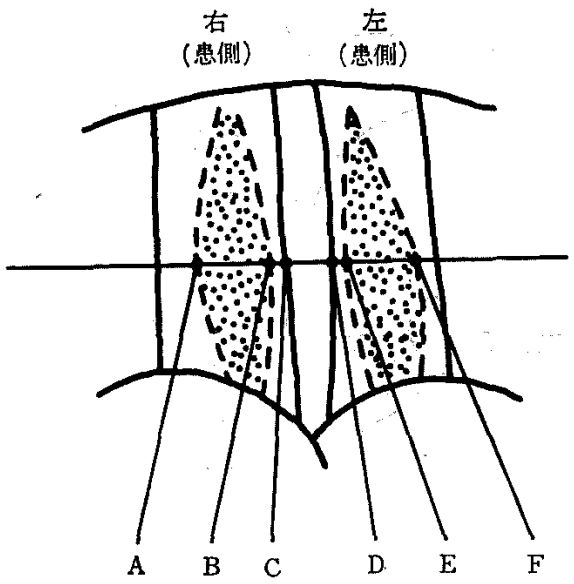

図 11 a 上皮肥厚性疾患の例の声帯の略図と測定点

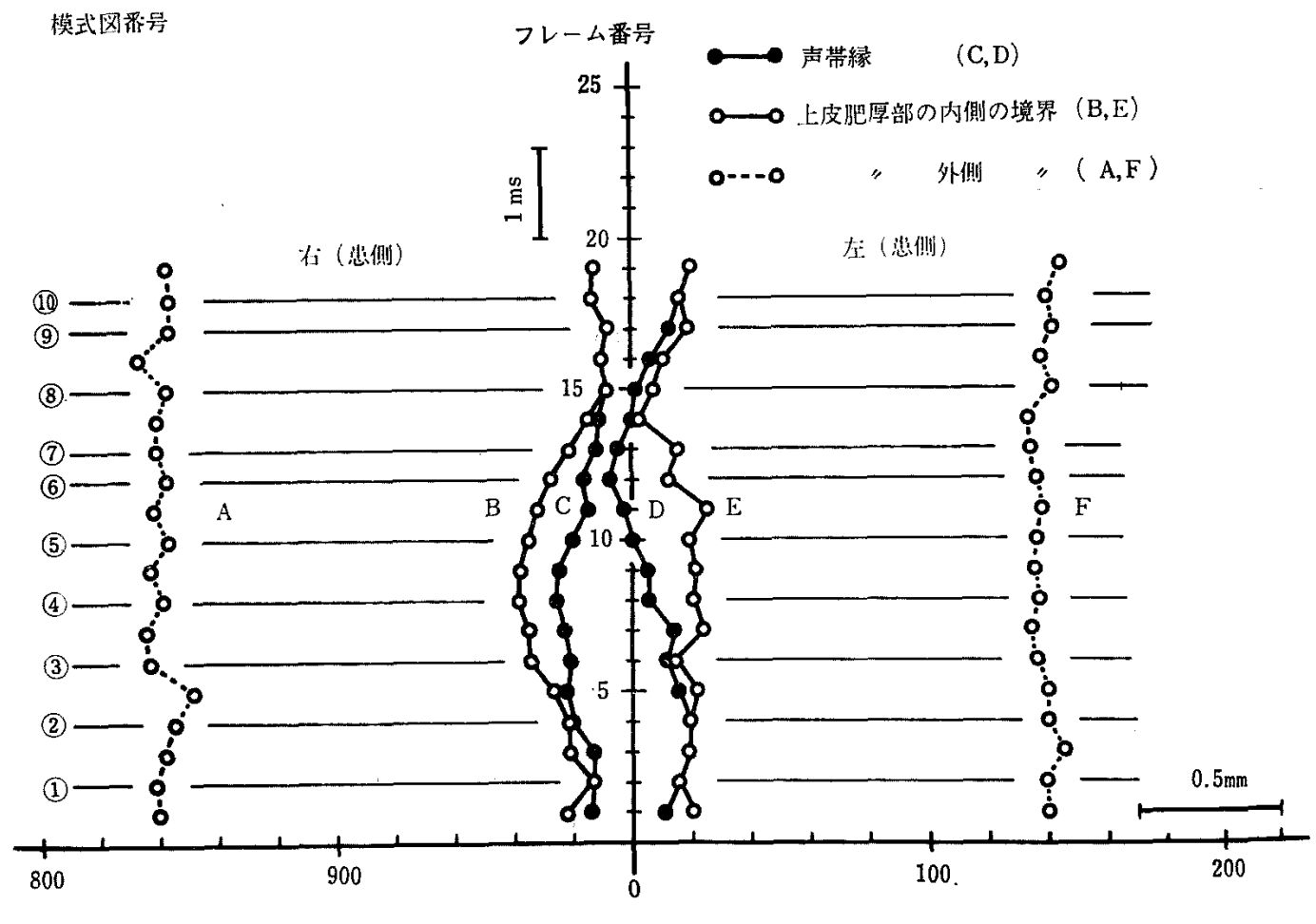

Film Analyzer $の$ 目盛

図 $11 \mathrm{~b}$ 四11a示した点の水平方向变位の時間变化 
(1)

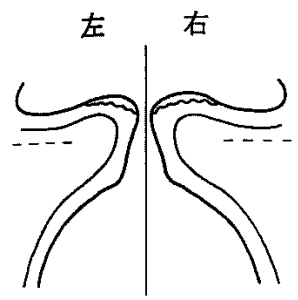

(3)

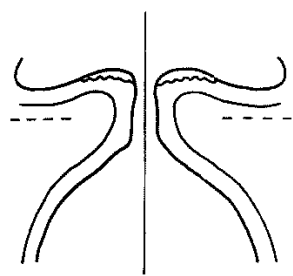

(3)
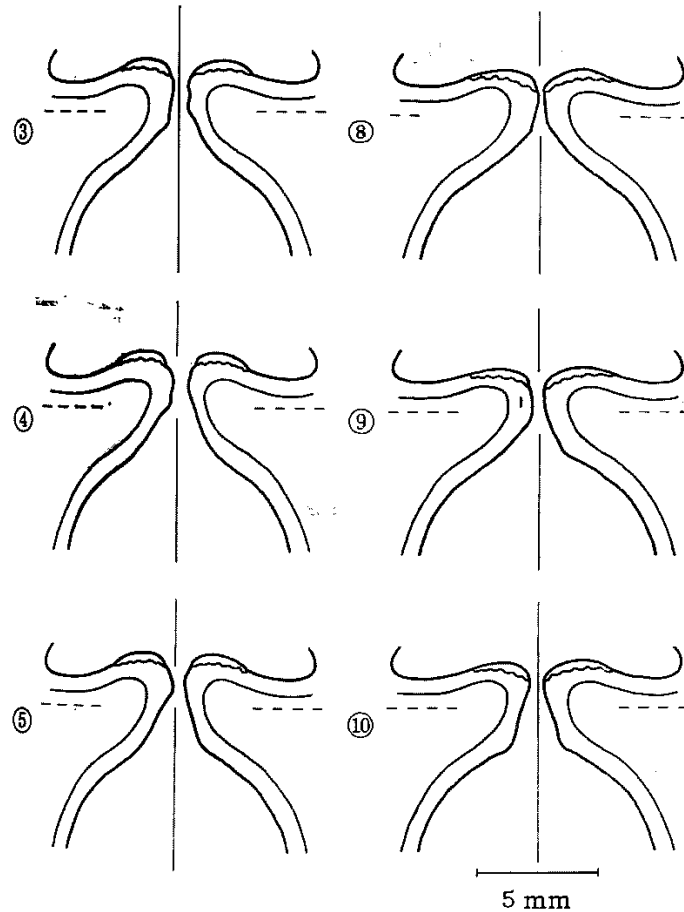

図 12 前額断面での声帯振動の模式図 （上皮肥厚性疾患，患側両側）

i） (1)から(6)まで健側声帯は $0.08 \mathrm{~m} / \mathrm{s}$ でゆるやが 閒大し，6で最大開大期となる．患側では(1)から (4) 亿か けて，吹きあけのため癌の部分がわずか上方へ首をも たけるため(3)から癌の内緑が観測される，乙かし，(4)で すぐ折りかえしてその反動て下方に向って首をふりはし
めるため，下縁は(5)で見えなくなる。

ii）趾側声帯は, (6から(9)まで閉小期であり，閉小速 度は開大期より速く，0.13 m/sである，患側では(5)か (9)のあいだ下方への首ふりもほほ停止してほとんど動き を示さない. (10で再び(1)の状態にあどる.

この振動の 1 周期は 23 フレームであるから， $7.7 \mathrm{ms，}$ したがって基本周波数は $130 \mathrm{~Hz}$ である.

\section{N. 総括ならひに考案}

前の報告つでは正常声带を対象としたが，本報告では 諸種の喉頭疾患々括ける異常声帯振動の前額断面に括け る模式的表示を行なった．前額断面の基本形は，発声中 の声帯のX線像, 声帯の組織学的な構造招上び各層の材 料力学的な性質などを考虑に入れて，等価的二層構造に 近似して模式化した ${ }^{1)}$.声帯汇発生する諸疾患の発生母地 となる層がほほ一定しているという事実2)から考兄て， このような層構造を考感した模式化は意義が大きい，

次に各疾患飞拈ける声帯振動の特徵を，正常声帯の場 合と比較して考察する，着目する特徽量惊，声帯振動の 最大振幅 $\mathrm{d}$ (最大水平変位幅), 最大変位速度 $\mathrm{v}$, そし て粘膜波動が生じる場合はその速度である．まず，正常

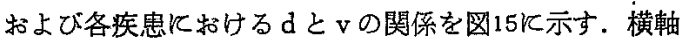
と緥軸怯それぞれdと $\mathrm{v}$ の刘数で目盛ってある. 理論的 な考察の結果， $\mathrm{d}$ 中 $、$ のきさは，振動体の材質炕関係

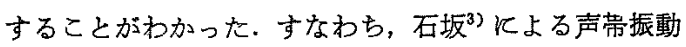
の1自由度モデルの運動方程式からdとvを表わす式を 導き，偏微分によって，質量，弹性，粘性などの変化が

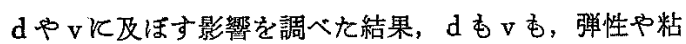
性の增加炕っって減少し，椞量や体積速度の堌加火よっ て增加する。 また図の概略の傾向では，dと vがほぼ比 例していることがわかるが，この比例関係からのずれの 分は，基本周波数と波形の並い加ら生じるものなので， ここでは言及しない，

図15の示す結果の所見を述へる前に，すで得られて いる声帯の組織学的所見2) 加ら種々の病変の場合の質量 と総合的に判断したみかけの硬さ（炶弾性に等侕で，硬 さの程度が增加するときは，粘性す弹性もとも飞增加す るとみなす） に着目してここに取り上げた症例拉よび 正常を比較すると，次の上うな大小関係が得られる。

質量：ポリープ

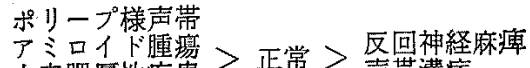
上皮肥厚性疾忽 $>$ 正常 $>$ 声带溝症 㜊頭癌 


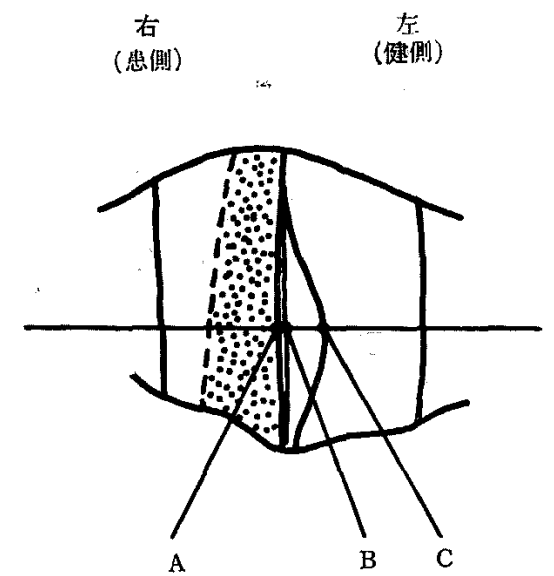

図 13 a 喉頭癌の例の声帯の略図と测定点

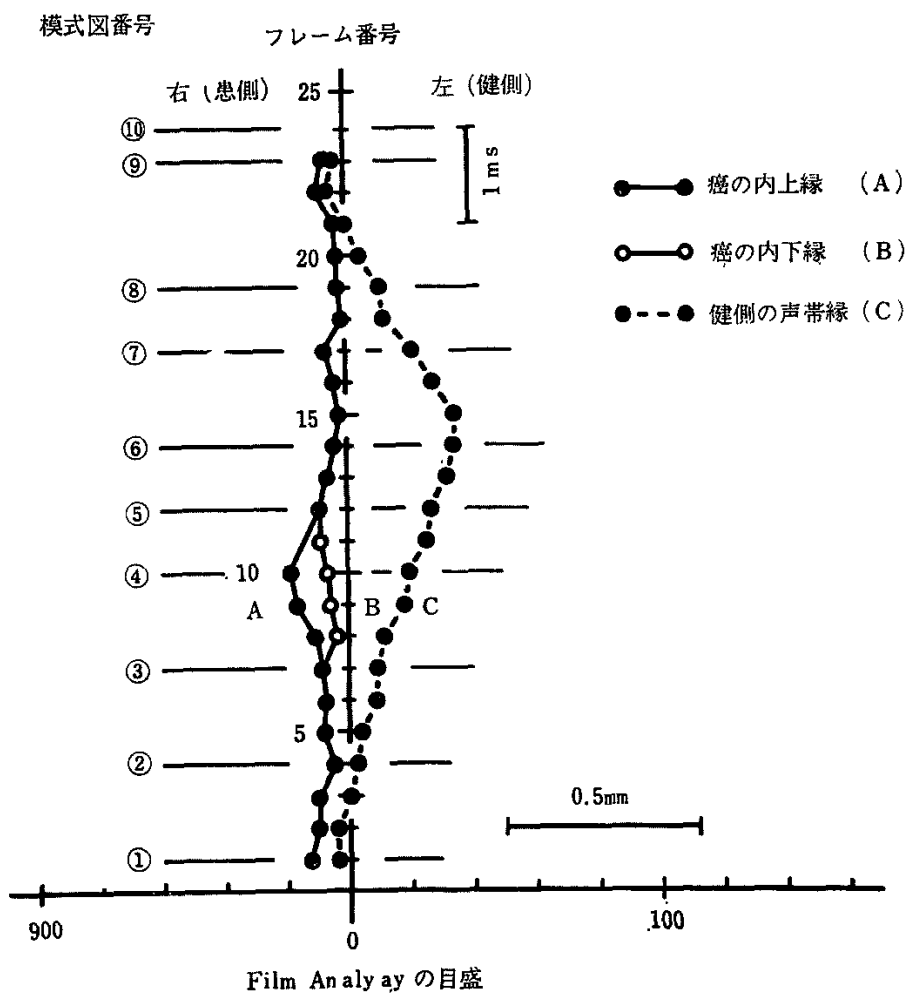

図 $13 \mathrm{~b}$ 図13aに示した点の水平方向変位の時間変化 
(1)

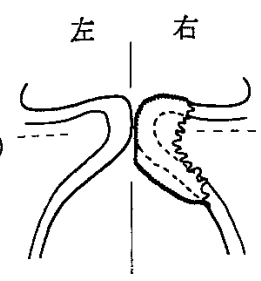

(2)

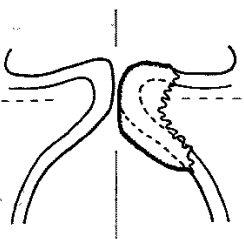

(3)

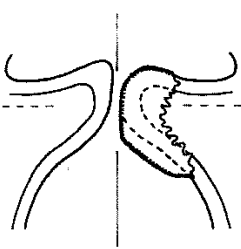

(4)

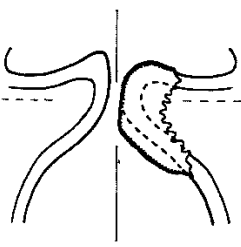

(5)

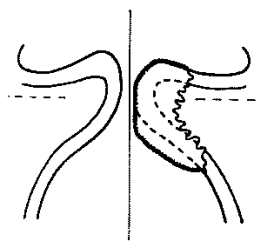

(6)

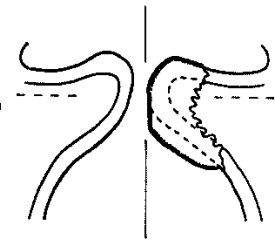

(7)

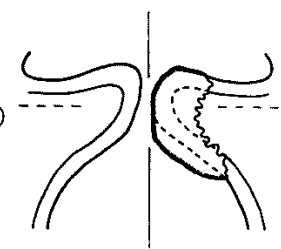

(8)

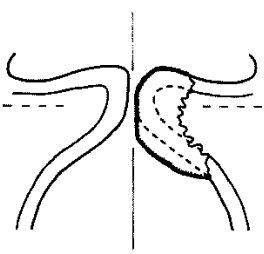

(9)

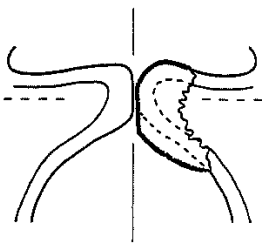

(10)

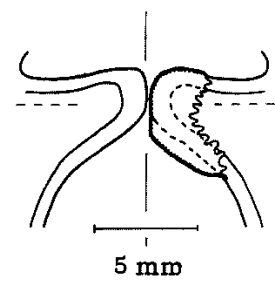

図 14 前額断面での声帯振動の模式図 （㗱頭癌，患側右）

組織の硬さ：

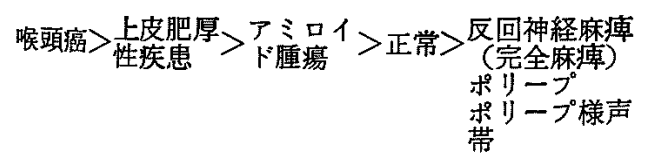

また，本諭文に示した例飞和いて反対側の声帯による妨 害の程度を示すと次のようである。

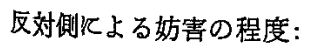

$$
\begin{array}{ll}
\text { ポリープ } & \text { 反回神経麻瘏 } \\
\text { ポリープ様声帯 }>\text { 正常 }>\text { 声帯满症 } \\
\text { アミロイド腫㾮 } \\
\text { 上皮肥厚性疾患 } \\
\text { 喉頭癌 }
\end{array}
$$

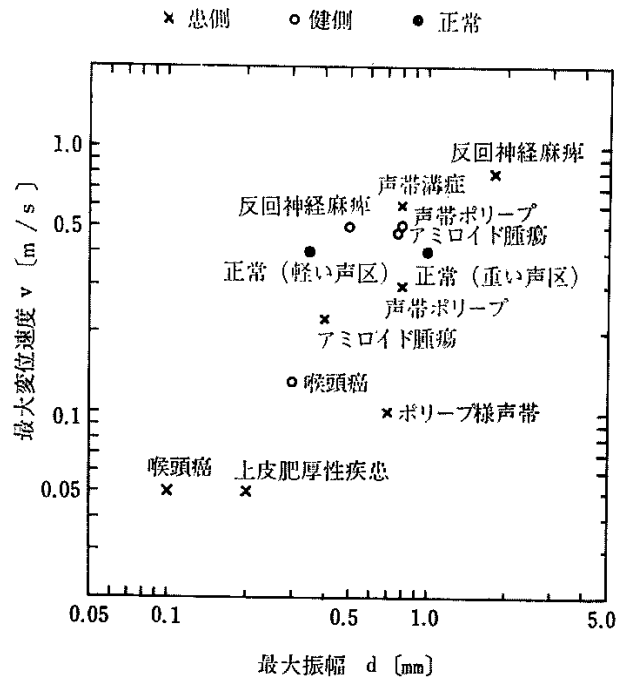

図 15 正常扰よび各疾患に括ける声帯振動の最大振 幅と最大变位速度の関係

以上の結果を図15の結果炕あてはめてみると，まず， 正常怙よび病変が片側性の例の健側(喉頭癌の例を除く) のグループがほほまをとっていて，dの值では少しばら つきがあるが，vの值は $0.4-0.5 \mathrm{~m} / \mathrm{s}$ でほほ一定であ る. 反回神経麻痺では, 質量, 硬さ共汇小さく, 正常扣 よび健側群上りd，vとむに大きい。前述の理論的結果 にあてはめると，この結果は，硬さの減少の方が質量の 隇少より香影響分大きいことを示す．声帯溝症は，質量 は正常より小さく，溝の部分の硬さは正常より大きいK もかかわらず，図15で、は正常よりわずが大きい。こ れは d の測定に際しては溝の底部でなく海の上下緑の動 きを追跡しているため, 清の底部の硬さの增大の影響よ りも, 振動部分の正常汇近い硬さの效果の方が表われて いると考元られる. ポリープ, ポリープ様声帯, アミロ 1 ト腫煌などの材質的飞比較的軟加い病变の例飞おいて は，硬さと質量のいずれ着目してむ正常よりd， $\mathrm{v}$ と あに大きくなると考えられる。しかしながらこの3例で は，いずれも反対側炕上る妨害が大さいため $\mathrm{d} ， \mathrm{v}$ とあ に抑制されて括り，図15にみられるごとく結果的には， 特に $\mathrm{v}$ 飞関して正常より小さい群となっている，上皮肥

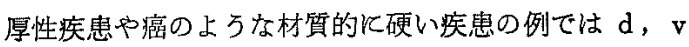
とあ著しく小さくなっている．以上のよろに $\mathrm{d} ， \mathrm{v}$ 振動体の質量, 硬さ, 他側加らの妨害の程度によってほ ほ規定され，影曏の程度は，硬さによるるのは質量とよ るあのより大きく，他側からの妨害によるものはさらに 
大きい，ただし癌の例の健側だけは例外で，病変がない にもかかわらずd, vが顕著に小さい。これは, 力んだ 音声から推察すると, 癌のため発声が困難な情沉下でど う火かして声帯振動を起こさせようとするためと，健側 声帯が異常に緊張しているためではないら考えられ る.このよろに最大振幅と最大速度の值は, 病変火上る 声帯の材質の变化のちがいをよく反映して扣り，特に最 大速度にこれがよく表われている。

一方，粘膜波县の速度は，波動加発生する場合は正常， 疾患氻かからず $0.5 \mathrm{~m} / \mathrm{s}$ 前後の一定の值が得られた. ただし癌では，健側，患側ともに粘膜波動を全く起こさ ない.したがって粘膜波動はその速度よりるむしろ発生 するかしないかが重要な特徴と考えられる。

以上の上うな結果は，病的声帯各層の等価的な質量や 粘弾性定数を推定する手がかりにあなると考光られ，声 带の材料的性質の病的な变化を察知する上飞有 用であ る. また本研究飞招ける模式化は, 病的声带の振動異常 のモデル的な説明や, 振動のシミュレーションなどを行 ろ際淿きわめて有用である。
V. 結 語

7 霾の啒頭疾㭧飞括ける声帯の振動然態を超高速度映 画によって撮影し，そのフィルムの画面を解析して結果

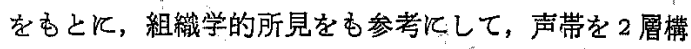
造汇近似した前額断面での振動の模式図を作成した. ま た, 声帯の最大振幅之最大变位速度, 阽膜波動の速度の 值の差異が，少なくとも現象的に，それぞれの疾患の特 徴をよくあらわしていることを示した。

\section{参考文献}

1）垣田有紀他：声帯の層榡造を考慮した振動状態の模

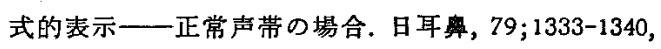
1976 (昭51).

2）平野”実：音声外科の基磪と臨床：耳算，21, 補 1, 239 440, 1975 (昭50).

3）石坂諫三: 声帯の振動飞関する研㶢. 東北大学博士 学位論文, 88 89, 1972 (昭47).

(原稿受付 昭和51，6.1日） 